\title{
Multi-Missioned Maritime Services: An Assessment of Proportional Approach of Inter-Agencies Operations in Nigeria and Malaysia
}

\author{
Abdulrazaq O. Abdulkadir ${ }^{*}$ \\ Taofeeq A. Abdulraheem ${ }^{2}$ \\ ${ }^{1}$ Department of Private \& Property Law, \\ Faculty of Law, University of Ilorin, Ilorin, Nigeria. \\ ${ }^{2}$ Department of Islamic Law, \\ Faculty of Law, University of Ilorin, Ilorin, Nigeria. \\ *Corresponding author: kor181law@gmail.com
}

\begin{abstract}
The interception of erring ships is one of the major tasks of maritime nations. The establishment of maritime agencies is done to protect seafarers, marine environments among others. Nigeria and Malaysia no doubt are two countries endowed with seas, and the two countries have enacted laws and established maritime agencies to tackle the menace of insecurity in ports and the maritime domains. The study compares the strategies for combating insecurity by maritime agencies in Nigeria and Malaysia. Interestingly, the two countries are also members of the International Maritime Organisation (IMO). Both countries, among other benefits, charge fees on cargoes loaded or unloaded in their ports. These charges significantly serve as sources of income, which enhances the economic development of the two nations. This paper examines the economic gains from the ports and maritime domain as well as the attendant risks inhibiting the fortunes derived from the seas despite legal and administrative machinery to surmount the challenges. The paper adopts methodological triangulation, and micro comparison to study or assess the phenomenon of various maritime security agencies at it enhances insight into their different approaches. This article gives a prognosis of some areas of benefits, interface, and shortcomings in the legal and administrative agencies of maritime security in Nigeria and Malaysia. It concludes by demonstrating that the laws regulating port and maritime security are virtually the same in both countries with little differences. It found that there is a lot to be learned from the implementation strategies of the Malaysian agencies especially in the areas operational disposition and this perhaps possible on the strength of basic amenities like stable electricity
\end{abstract}


which is one of the panaceas to tame stowaway passengers among other insecurity in the port and maritime domain.

Keywords: Maritime, Interception, Interface, Assessment, Operation.

Received: 18/11/2019 Revised: 23/03/2019 Accepted: 13/06/2020 Published: 30/06/2020

\section{INTRODUCTION}

There have been legal regulations and administrative agencies of maritime security established in Nigeria and Malaysia. Although noticeable distinctions are seeing in some of the provisions of the laws of the two jurisdictions, the laws are enacted to achieve the same purposes. In addressing the comparative analysis of these legal regulations, this research adopts a micro comparison to deal with the issue of ports and maritime security. Micro comparison is a system of comparative law which makes use of a strategy adopted in other jurisdictions of concern to deal with specific problems to solve a given problem (Zweigert, K. and Kotz, H., 1987). This paper identifies the benefit from the effective implementation of the legislation of the two countries under consideration, and it is against this background that the micro comparison method of comparative law is deemed suitable. Significantly, writers have observed that there is the proclivity of the inability of the legislature to produce good laws without the assistance of comparative law (Zweigert K. and Kotz H, 1987), hence the rationale for the adoption of the micro comparison method in this paper.

The obvious is that the two countries have a natural endowment of the seas, which culminates in maritime commerce and perhaps increases their economic fortunes. The loading and unloading of cargoes, crude oil, containers, etc. by vessels from different parts of the world to and from attract levies. The two countries, among other advantages, charge fees on cargoes through customs officers at ports, which serve as sources of income and thereby enhance economic development. Despite the fact that it has been discovered that economic gains from the ports are not without their attendant risks, that is why the need for stringent measures that will check the menace.

Given that, enforcement frontiers have been immense roles in conducting surveillance in maritime domains. As expected, the issue of importation 
weapons through the maritime domain is capable of threatening the security of nations. At the same time, the pollution of the marine environment by foreign-flagged ships in the course of enjoying the right of access to ports granted under The 1923 Convention is also capable of depriving a country of its marine resources. Therefore, where a vessel breaches any of the conditions stated under the national laws, the right to decline right of access to ports should be provided under a local enactment.

\section{POLITICAL ARRANGEMENT AND LEGISLATIVE PROCESS}

\section{Nigeria}

Nigeria's political practice is federal, and this is based on a written constitution whereby the federal, states and local government tiers are in operation. By this practice, powers are distributed among these various systems of government within their political territories and each tier with its separate allocation coming directly from the federation account, as stated under the 1999 Constitution of the Federal Republic of Nigeria. However, each tier generates internal revenue independent of allocation from the federal government.

It is the practice that an individual, through a political party, assumes office as President, governor or local government chairman after the election must have been conducted by the electoral body known as the Independent National Electoral Commission (INEC) or States Independent Electoral Commission, as the case may be. Political office holders hold their respective offices for four years. This is subject to the power of impeachment exercisable by the National or State Assembly (See sections 143 and 188 of the Constitution of the Federal Republic of Nigeria, 1999) and may be re-appointed by the electorate for another term of four years and no more.

Nigeria, as presently constituted, has 36 states, 774 local government areas, and a Federal Capital Territory (FCT, Abuja) (See part 1, first schedule, section 3, 1999 Constitution). The law-makers are elected from the various constituencies as members of the State Houses of Assembly and National Assembly to make laws for the good governance of each state and the country, respectively. These representatives (law-makers) in the National Assembly have enacted laws relating to port and maritime security examined in this paper. By this political arrangement, there are matters which are within the exclusive legislative power of the National Assembly to make law, and these 
are issues within the control of the federal government of Nigeria. Among these are the issues of ports and maritime security, which are the subject matter of this thesis. The National Assembly makes any law relating to the establishment, control, and management of ports through an Act of National Assembly. It is based on this that the Federal Government of Nigeria exercises absolute or exclusive powers on Nigerian ports and maritime security as well as its regulatory agencies.

\section{Malaysia}

Malaysia, whose name is synonymous with water, on the other hand, operates a written constitution modeled in line with the Indian Constitution with basic principles of the British system of government (Ahmad Ibrahim, 1974; Sharifah Suhana Ahmad, 1999). Like Nigeria, the Federal Constitution is supreme, and any law inconsistent with the Federal Constitution shall to the extent of its inconsistency, be void (Article 4(1). The issue of supremacy of the constitution came before the court in the case of Public Prosecutor v. Dato' Yap Peng(1987) 2 MLJ 311). In this case, the court, while interpreting section 418A of the Criminal Procedure Code, held that it was inconsistent with Article 121(1) of the Federal constitution (as it was). According to the court, Article 145(3) does not empower the parliament to confer the power of transfer of a case from the subordinate court to the High Court on the Public Prosecutor. Therefore section 418A is void to the extent of its inconsistency with the Federal Constitution(See the decision of the court in Surinder Singh v. The Government of the Federation of Malaya (1962) MLJ 169).

Malaysia operates a parliamentary system of government with the head of government and ceremonial head. The Yang-di Pertuan Agong is the ceremonial head or head of state which acts following the advice of the Cabinet (Sharifah Suhana Ahmad, 1999). The Prime Minister, on the other hand, is the head of government-appointed among the Cabinet members (Sharifah Suhana Ahmad, 1999). The practice in Malaysia is similar to that of the British government except in certain instances where some distinct approaches appear. Presently, Malaysia is made up of 13 (Ahmad Ibrahim, 1997) states and three federal territories and each state having a separate constitution and a Ruler or governor acting upon the advice of the State Executive Council.

One of the unique features of the control and management of ports in Malaysia, unlike Nigeria, is under the Concurrent List, whereby states and 
the federal government have powers to manage and control. This informed the reason for some ports and jetties are under the control of some state governments. This marks one of the distinguishable areas when compared with the position in Nigeria where all ports are deemed federal ports.

\section{EXISTENCE OR PRIVILEGE OF THE SEAS}

\section{Nigeria}

Nigeria as a country is endowed with the sea, and it has maritime zones over where it is exercising sovereign rights to all living and non-living resources comprising of an Exclusive Economic Zone (EEZ) from 22-370kms, a contiguous zone of 22-44kms and a territorial sea of $22 \mathrm{~km}$ (Ogah P, 2012). It has been observed that this maritime domain constitutes more than $30 \%$ of the total landmass of Nigeria, and it includes the sea area known as the Gulf of Guinea (GOG) (Ogah P, 2012).

Consequently, the domain's socio-economic advantage and the strategic significance of the entire area are enormous to Nigeria (Abdulkadir, A.O, 2015). Nevertheless, there is a need for consistent efforts at strengthening the port and maritime domains concerning the capability of security agencies in the enforcement of the legal regulations in terms of surveillance activities. The territorial waters of Nigeria extend to $12(\mathrm{~nm})$ of the coast of Nigeria and the baselines, low tide along the coast, and the straight lines join the most advanced points of the coast, including the mooring places, hydro-technical works, islands, and other permanent harbor installations. The waters situated between the sea coast and the baselines constitute the internal waters of Nigeria. Nigeria, as a nation, has been said to have about $870 \mathrm{~km}$ and 3,000 $\mathrm{km}$ of coastline and inland waterways, respectively, and also 913, 075 square meters in land mass (Okeke V.O.S and Aniche E.T, 2012). Nigeria's natural resources include natural gas, coal, zinc, limestone, crude oil, columbite, tin, iron ore, lead, etc. with a population of over 150, 000 million. It has been observed that Nigeria has a cubic feet reserve of gas of about 600 trillion, which is estimated at 40 billion barrels of crude oil with 3-5 cubic meters of another natural resource known as Bitumen (Okeke V.O.S and Aniche E.T, 2012). It is beyond peradventure that these resources have economic value to Nigeria with respect to foreign earnings, and they are also directly interrelated to the maritime part of the respective industries. For instance, the oil and gas sector of the economy is predominant in Nigeria's short sea commerce, and it constitutes approximately about $95 \%$ coastal and inland shipping. 


\section{Malaysia}

Maritime Zone of Malaysia consists of the Territorial Sea 12 (nm) (Emergency (Essential Powers) Ordinance, No. 7 1969, section 3 (1)where all ships enjoy right of innocent passage, a Contiguous Zone $(24 \mathrm{~nm})$ with the power to enforce customs, immigration, fiscal and sanitary laws (UNCLOS Article 33), an Exclusive Economic Zone (EEZ) $(200 \mathrm{~nm})$ (Exclusive Economic Zone Act 1984 (660), section 3(1) with the right to exercise control and management of living resources but this is subject to the right of other states on the right navigation under the Article 87 (1), UNCLOS and a Continental Shelf $(200 \mathrm{~nm})($ Continental Shelf Act 1966 (83), section 2).

The Malays have always regarded the seas bordering their country as natural appurtenances and, therefore, under its absolute sovereignty. This concept, which emphasizes the unity of the country's land and water, is reflected in the Malay term for native "land-water."Malaysia signed the1982United Nation Convention on the Law of the Sea on $10^{\text {th }}$ December 1982, and ratified it fourteen years later, precisely on $14^{\text {th }}$ October 1996. Historically, peoples of the South East Asia region have, in general, organized their lives within the context of surrounding land and seas. The coastal Malays, in particular, regarded the sea as a natural appurtenance to the land they occupy (Tunku Sofiah Jewa, 1996). Sovereign states exercised absolute sovereignty and jurisdiction in seas such as the Straits of Malacca, the Celebes Sea, the Sulu Sea, and the South China Sea, which encompass the Malay Peninsula and the Malay Archipelagos. The seas surrounding the land played a significant role in the defense, economic, and political matters of Malaysia. Malaysia presently has a plethora of port and maritime laws. Malaysia's participation in $20^{\text {th }}$ century international trading and the influence accorded by the development of world-wide laws of the sea since the advent of Western European dominance in Ocean-related matters (Gold .E, 1981) precipitated the establishment of a somewhat irregular mix of national and international legislation in Malaysia. Malaysia's earliest recorded $20^{\text {th }}$-century national law, which considered the management of internal waters remotely, is the Waters Act 1920, enacted to provide for the control of rivers and streams.

Apart from being a party to the 1982 UNCLOS, Malaysia is a party to many other port and maritime-related treaties that influence the use and management of Malaysia's maritime domain. The Malaysian membership of the International Maritime Organisation and subsequent ratification of the 1923 Convention and Statute on the International Regime of Maritime Ports 
are testimony (Other examples in this category include Safety of Life at Sea Convention (SOLAS), 1974, Load Lines Convention, 1996, Civil Liability Convention, 1969, Standards of Training, Certification and Watch Keeping Convention (STCW) 1978, Agreement on the International Association of Lighthouse Authorities Maritime Buoyage system, 1982 etc.).Malaysia has also been involved directly in pursuing national interests at the international level regarding the expansion of maritime jurisdiction for the purposes of security and self-preservation, resource exploration and exploitation, and political well-being.

Based on the above background, it has been demonstrated that the comparative analysis of the legal framework and regulatory agencies of the two countries in relation to port security is reasonable. It will enhance performance through their various experiences in the application, enforcement, and efficacy in the management of the port and maritime security.

\section{CROSSING POINT OF THE LEGAL REGULATIONS}

\section{Port Authority Acts}

\section{Managing Security Forces}

An assessment of the provisions of the Malaysian Ports Authority Act indicates that the port authorities have the power to establish a security force (though subject to the approval of the Minister) for keeping order and security within the premises of the port (See Malaysian Ports Authority Act, section 13a (1). This is to ensure that the free flow of commercial activities are not in any way disturbed by external agents whose agenda is to disrupt the economic fortunes of the nation through ports. Where the port security personnel discovers any security gap, the provisions of the Act empowers them to arrest and handover the suspect to the police (sections 13(3) \& (4) which provides:

"...a member of the security force shall have the power to arrest without warrant any person found on any premises of the authority or in premises in the possession or under the control of the authority, or any part thereof, without lawful excuse." "Every person arrested pursuant to subsection (3) shall be taken to the nearest Police Station as soon as possible..." 
Contrary to the above, the Nigerian Ports Authority Act is silent and makes no provision for the management of the Authority to have a security outfit than those created by other statutes like the Navy, Customs, Immigration, Marine Police, etc. to maintain law and order in ports. The Nigerian Ports Authority would benefit immensely if a security force, different from the regular one, is established in ports to protect the port environment from gangsters. For example, if this kind of arrangement is in place, it would prevent the issue of an unauthorized person impersonating as a pilot in ports for pilotage, which is likely to expose vessels, passengers, and cargoes to danger. Alternatively, the Nigerian ports authority can make use of members of the Nigerian Security and Civil Defence Corps (NSCDC) in order to save costs.

\section{Merits}

It is posited that where Ports Authorities Management have a security outfit under its control, the following benefits are realizable:

a. It gives the management of the port authority the power to appoint guards at ports to protect port facilities;

b. It enables the port authority to identify a specific officer who is not efficient in the case of a security gap and damage to port facilities; and

c. It prevents some minor crimes that are often committed in ports.

\section{Demerit}

The arrangement of keeping a security outfit by port authorities involves extra expenses on the part of the management of the port authority. Nonetheless, where the agency makes use of security officers like the Nigerian Security and Civil Defence Corps, the issue of cost implications will not arise. This is because the corps is established and being paid for by the Federal Government of Nigeria.

\section{Merchant Shipping Acts}

The new amended Merchant Shipping Act, 2007 of Malaysia, which replaced the Merchant Shipping Ordinance of 1952, contains provisions for compliance and issuance of the International Ship Security and Safety Certificate of a designated marine facility. This arrangement would enable a vessel to put in place specific security and safety measures which the master or crew must implement (see sections 249A and 249k (4) (a) and failure to implement 
may, by implication, deny a vessel the right of access to Malaysian ports. The Merchant Shipping Act of Nigeria 2007 also provides for the registration of ships in Nigeria or evidence of registration in the flag state of the foreign ships before an operation in Nigerian waters (See section 5 (1). This is to identify ships traversing and transacting business in Nigerian waters. The registration of ships under the Nigerian Act also prevents a threat to the port and maritime domain connected with the discharge of waste that affects the maritime environment. Unlike the Malaysian Shipping Act, there is no provision in the Nigerian Shipping Act, which empowers the agencies like NIMASA to issue the ISPS Compliance Certificate to deserving ships. The provision is an excellent innovation and could be harnessed or incorporated into Nigerian law. The two Acts under consideration are virtually aimed at achieving the same goals with little variation.

Interestingly, in the event of the release of diseases at border ports through the Act of bioterrorism activities, there is no specific legislation in Malaysia to address the issue. The Shipping Act, MMEA Act, etc. can be amended, or new legislation is enacted to cater to this lacuna. The Malaysian government is yet to have domestic legislation incorporating the Convention on the Prohibition of the Development, Production and Stockpiling of Bacteriological (Biological) and Toxin Weapons and on Their Destruction (BWC) of 1972 which it had ratified since September 6, 1991. Although, a bill to this effect has been drafted, the bill is yet to see the light of the day. However, in the case of Nigeria, apart from the fact that the Nigerian Terrorism Act mentions that bio-terrorism is prohibited (Terrorism Act 2011, section $1(2)(\mathrm{c})(\mathrm{v})$, there is no provision which addresses the occurrence and what more of penalty thereto. Therefore, there is a need for legal regulation projected and precautionary measures provided that should reduce the calamity of the release of the diseases among the populace. It is humbly suggested that the Nigerian and Malaysian governments should improve on the lapses identified and bridge the gap of the legal regime.

\section{NIMASA and MMEA Acts}

The Nigerian Maritime Administration and Safety Agency (NIMASA) and the Malaysian Maritime Enforcement Agency (MMEA) were established by Nigeria and Malaysia, respectively. The essence of the two laws is for the establishment of the agencies that will be carrying out maritime enforcement activities in their respective sovereign state. The agencies are headed each by a Director-General appointed by the President on the advice of the Minister in the case of Nigeria, and by the Yang-Di Pertuan Agong on the advice of the Prime Minister in the case of Malaysia. 
Essentially, the issue of qualifications of the Director-General of these agencies calls for concern. For a person to be appointed as a DirectorGeneral of the Nigerian Maritime Administration and Safety Agency, he/she must have extensive knowledge of maritime affairs (NIMASA Act, section 11). However, in the case of Malaysia, it is observed that the Act is silent on the qualifications of a civil servant to be appointed as the Director-General of the MMEA. This gap needs to be addressed by inserting a provision in the Act that will make only a civil servant with requisite knowledge of port and maritime security to be appointed as the Director-General; otherwise, the agency may not achieve its mandate if a non-technocrat is put at the helm of affairs. Where a Director-General who is not a technocrat in port and maritime security is appointed to manage maritime affairs, obviously he/she would lack the sense of directing, controlling, and managing all the security agencies involved in the struggle to build national security at border ports. The adoption of the NIMASA Act provisions on this position is apt.

\section{Cabotage and Fisheries Acts}

The enforcement regime concerning fisheries regulation in Malaysia is stringent in that the country has developed a strategy to monitor fishing vessel activities within the Malaysian EEZ. The strategy is that a license issued to vessel owners is only valid for 12 calendar months from the date of issuance (Fisheries Act, section 14) and foreign vessels are not allowed to engage in fishing activities in Malaysian waters unless authorized to so doing by the International Fisheries Agreement between the government of Malaysia and the government of the country of the fishing vessel(Fisheries Act, section 15). Therefore, where there is any contravention of the provisions of the Fisheries Act or any subsidiary legislation in relation to that, the master, owner and members of the foreign vessel shall be guilty of an offense (Fisheries Act, section 24) and the offense shall be deemed to have been committed in Malaysia to confer jurisdiction on the court. The court of competent jurisdiction in this regard includes a Sessions court and Magistrates court of first-class grade (Fisheries Act, section 32). Where it is established that the vessel so arrested has breached the provision of the Act, the court has the discretion to order forfeiture of the vessel that is arrested.

It merits mentioning that any authorized officer has the power of enforcement to ensuring compliance with the provision of the Act. This, the officer can exhibit by the board, stopping and searching any vessel within Malaysian 
Fisheries waters and conduct examination and inspection on a vessel (Fisheries Act section 46).

The above representation is not the case in Nigeria. In order to promote indigenous tonnage, fishing in Nigerian waters is restricted to vessels that are manned and wholly owned by Nigerian citizens. It is an attempt to encourage and develop the sector through the participation of citizens (Cabotage Act, 2003, section 3-6), and thus, little opportunity is accorded to foreign vessels.

Concerning the penalties imposed in the case of illegal fishing, the two jurisdictions have similar provisions except for inadequate enforcement and surveillance equipment that are obtainable in the case of Nigeria coupled with prosecution bureaucracy (Ganapathiraju Pramod and Tony J Pitcher, 2012). It is suggested that the security measure needs to be improved in Nigeria in order to actualize the aims and objectives of the Act to benefit indigenous shippers.

Importantly, where a vessel is within the Exclusive Economic Zone of Malaysia any offense committed on board by a passenger against another passenger which ordinarily affects the peace and order of the country, the Malaysian government has unfettered discretion to punish the offender following the appropriate domestic law (Penal Code (Act 574), section 4). The adoption of this provision of the law in Nigeria will also be apt. In the same token, adoption or incorporation of the principle enunciated in the cases of Mali, Consul of His Majesty, the King of the Belgian v. Keeper of the Common Jail of Hudson County, New Jersey (1887) 120 U.S 1, United States v Fores, 289 U.S 137, 155-159 and Cunard Steamship Co. v Mellon, 262 U.S. 100. 124, which empowered port states to punish an offender into the Nigerian and Malaysian Ports Acts, will be a synergy to bring the offense to the attention of the people engaging in fishing activities.

Besides the above legal regulations, other Acts that deal with port security problems in both Nigeria and Malaysia are virtually the same, although their implementations are different based on political will and efficiency of the regulatory agencies concerned. The figure below shows the areas of distinctions between the legal regulations in Nigeria and Malaysia: 
JGD Vol. 16. Issue 1, June 2020, 1-20

Table 1.

Showing Areas of Differences in Nigerian and Malaysian Laws

\begin{tabular}{|c|c|c|}
\hline \multirow[t]{2}{*}{ Description } & Nigeria & Malaysia \\
\hline & \multicolumn{2}{|r|}{ Ports Act } \\
\hline $\begin{array}{l}\text { Managing security } \\
\text { forces }\end{array}$ & Nil & Section 13 a (1) \\
\hline \multirow[t]{2}{*}{ Power of Arrest } & Nil & Section 13(3) \& (4) \\
\hline & & Merchant Shipping Act \\
\hline \multirow{3}{*}{$\begin{array}{l}\text { Issuance of ISPS } \\
\text { Code Compliance } \\
\text { Certificate }\end{array}$} & Nil & Section 249 A \\
\hline & & \\
\hline & NIMAS & Act and MMEA Act \\
\hline \multirow{2}{*}{$\begin{array}{l}\text { Appointment of } \\
\text { D.G. based on } \\
\text { knowledge of } \\
\text { maritime security }\end{array}$} & Section 11 & Nil \\
\hline & \multicolumn{2}{|c|}{ Cabotage Act and Fisheries Act } \\
\hline $\begin{array}{l}\text { The validity of } \\
\text { Licence for Fishing }\end{array}$ & Nil & Section 14 provides for 12 months \\
\hline
\end{tabular}

\section{REGULATORY CONTROL OF PORTS}

Apart from the above-identified areas of the interface in the two jurisdictions under consideration, there are other areas of distinction in the operational system of ports which could be gleaned from the following:

\section{Ownership of Ports}

\section{Nigeria}

In Nigeria, ownership, control, and management of ports are vested in the federal government of Nigeria. The establishment of ports as contained under the Nigerian Constitution is within the exclusive legislative lists, which presuppose that only the federal government of Nigeria is vested with the power to establish, control, and manage ports. (See generally, item 36 
of part 1 of the Exclusive Legislative List of the 1999 Constitution of the Federal Republic of Nigeria (as amended) which provides that the Federal government shall have the exclusive legislative power to make law in respect of Maritime shipping and navigation, including:

(a) shipping and navigation on tidal waters; (b) shipping and navigation on the River Niger and it's affluent and on any such other inland waterway as may be designated by the National Assembly to be an international waterway or to be an interState waterway; (c) lighthouses, lightships, beacons and other provisions for the safety of shipping and navigation.

Unlike Malaysia, in Nigeria, states lack the power to establish or designate a port as a state port. Therefore, establishment, ownership, control, the appointment of the Chief Executive and Directors of the Authority, etc. are all under the power of the federal government (See the Nigerian Ports Authority Act, 2004, section 10) which provides;

“...There shall be, for the Authority, a managing director to be appointed by the President and, 10 (4) (4) The President shall appoint for the Authority, three executive directors to assist the managing director in the performance of his functions under this Act...".

This can also be gleaned from the fact that any action instituted against the Nigerian Ports Authority particularly those that relate to the establishment of ports, admiralty, and maritime issues, are filed before the Federal High Court (See section 251(1) (g) of the 1999 Constitution).

“....any admiralty jurisdiction, including shipping and navigation on the River Niger or River Benue and their affluents and on such other inland waterway as may be designate by any enactment to be an international waterway, all Federal ports, (including the constitution and powers of the ports authorities for Federal ports) and carriage by the sea...".

It is against this background that the Federal High Court is vested with original jurisdiction on the aforementioned related issues of the Nigerian ports. However, where the issue involved does not concern with those mentioned under the constitution(the Constitution of the Federal Republic of Nigeria, section 251(1) the Federal High Court will be divested of the jurisdictional competence to hear and determine the case. This position was given judicial flavor by the Nigerian Supreme Court in the recent case of 
Ports and Cargo Handlings Service Company Limited \&ors v. Migfo Nigeria LimitedSC.42/2009, delivered on $8^{\text {th }}$ June 2012. See also S.O. Ntuks $v$ NPA, SC.190/2003, delivered on $11^{\text {th }}$ May 2007.

\section{Malaysia}

Contrary to the position in Nigeria as stated above, ports are either established as state or federal ports in Malaysia, and each port is under the control of their respective governments (state or federal). This is adequately provided for under the Federal Constitution of Malaysia (Article 73-75, Federal Constitution of Malaysia). The parliament in Malaysia has exclusive power to make laws in respect of matters contained under the federal list as well as the concurrent list of the Federal Constitution. On matters under the federal list, the state legislature cannot make law in respect thereof, while in the case of matters stated under the concurrent list, both the federal and state have powers to make legislation. An example of a matter in Malaysia wherein both the Federal and State legislatures can make legislation is 'port', that is, the states' legislative assemblies will have the power to make laws on ports designated as state ports, and parliament makes the law on ports designated as federal ports. Also, there are ports and jetties which are under the jurisdiction of the Marine Department; fishing ports and jetties are under the jurisdiction of the Fisheries Development Authority, and oil majors operate their particular ports. All these are quite different from what is obtainable in Nigeria.

\section{Security Implications}

The idea of ownership and control of specific ports by states might have its desirability, the security implications of the initiative worth consideration. Ports and maritime commerce play significant roles in the economic advancement of coastal states and so also its attendant security challenges, which require effective legal frameworks and efficient security personnel to combat any attempt to deny coastal states their economic fortunes. In order to face challenges of port and maritime security, various countries have their armed forces like the Navy, Army, Marine police, etc. to ensure the safe sea for their country to enjoy the benefit of the maritime zones. These security outfits are under the control and management of the federal government (Nigeria and Malaysia in the instant case), and therefore allowing some states to own, control and manage ports are likely to provide a security gap, which may give rise to external aggression of non-traditional security threats. The point here is that states lack the necessary power to assert control and 
Authority on the regulatory agencies of maritime security, and the priority of state governments that own ports would be to foster or generate revenue for the states, thereby putting the issue of security as secondary, which should be avoided as much as possible.

The control and management of ports under centralized management, as in Nigeria's case, are desirable for there to be partnerships with private enterprises that act as concessionaires for public installations or advancement of ports with a series of sophisticated equipment for the port to have a worldclass outlook. The concept of public value, protection of public property, and maintenance or satisfaction of collective public needs are germane for the development of infrastructure of port facilities. In any event, the government will incur expenses in carrying out the development. Thus the government will attempt to realize interests from its investment in addition to the allocation accruable to the state from the central government. The decentralization of ports wherein state participation is allowed to manage might be problematic if the state concerned is left to handle external security concerns. The issue of whether a port is under the control and management of state or federal, the cardinal responsibility of the government concerned is the need to safeguard the port against security threats that is capable of devastating the peace and orderliness of a nation. However, the best tier of government to handle it is the federal government. The security arrangement to be put in place in ports often rests under the control of the federal government, and it is safer than the ownership of ports rests on the central government since it is an issue that involves ratification of international treaties and conventions coupled with the fact that control of security personnel is a sacred responsibility of the federal government in order to assert sovereignty and national security of its territory.

\section{ENFORCEMENT STRATEGIES}

\section{Administrative Agencies}

The enforcement strategies of port and maritime security are virtually the same if compared, and these include the navy, marine police, immigration, customs, etc. It is not deniable that the existence of good laws without viable institutions to implement them is akin to no law at all being in existence (Abdulkadir O. A, 2014). This is because a legal instrument only becomes valid if adequately implemented. Implementation by its enforcer determines its efficacy. Accordingly, administrative and institutional agencies are contributors to the development of the port and maritime security. The 
implication of this is that a well-designed law that is not well implemented by the institutional or administrative agencies can affect national security, thereby hindering development in the state concerned (Nigeria and Malaysia).

The presence of the seas, which has culminated in the establishment of the ports in Malaysia and Nigeria, has given rise to the protection of ports and the maritime zones. Generally, the protection of the ports is against unscrupulous elements among humans who derive pleasure in the destruction of the port facilities and importation of destructive weapons through ports in order to achieve material gain (UNCLOS 1982, Article 101) or political popularity. Therefore, where a ship engages in the carriage of weapons of mass destruction, port security agencies can deny access to such ships. These challenges have called for the introduction of personnel with requisite skills to combat the threats posed by these dastard activities. The threats of port or maritime security have prompted the government of various nations, including Nigeria and Malaysia, to establish agencies to tackle the issue of port security.

Therefore, both Nigeria and Malaysia established regulatory agencies to implement and enforce the legal framework on ports and maritime security as the law would only be effective if there are agents saddled with the responsibility of ensuring compliance with the provisions of the law. The regulatory agencies of port security in Nigeria and Malaysia are identical with the similarity of purpose ranging from the ports authorities, the navy, customs, immigrations, marine police, maritime Institutes, etc. The apparent distinction among the agencies majorly is in the area of effectiveness of their operations as well as compliance with International Maritime Organisation (IMO) regulation with Codes like International Ship \& Port Security Code (ISPS Code), Nigerian Maritime Administration and Safety Agency (NIMASA) has not been effectively proactive on the implementation of the Code, (Abdulkadir, A.O, 2013) Container Security Initiative (CSI) and the likes.

Considering the number of containers and other cargoes that a single ship might import at a particular time in the Nigerian ports, manual inspection onboard a ship is not capable of yielding the desired results of preventing the importation of harms into the country. Therefore, compliance with the ISPS Code arrangement by the IMO is a panacea at reducing the Container Security Initiative (CSI) problem.

Therefore, implementation of the IMO Container Security Initiative, which is patently lacking in Nigeria, is a vital tool towards achieving the goals of 
thwarting the menace of trans-boundary harms through the border ports. The idea of inspecting containers one after the other is archaic and gives room for importation of harms because a substantial number of containers would be left without inspection.

It goes without saying from the above exposition that the Nigerian port security agencies are experiencing difficulties which perhaps are responsible for the importation of harms through the Nigerian border ports. It is therefore suggested that facilities be put in place in Nigeria to enable the port and maritime security agencies to perform their functions like their Malaysian counterparts. Where facilities are in place, ships that fail to meet conditions for entry to port can be denied the right of access. The following figure shows the areas of differences between administrative control and strategy of port security in Nigeria and Malaysia:

Table 2 .

Showing Areas of Differences between Administrative Control and Strategy of Port Security in Nigeria and Malaysia

\begin{tabular}{|c|c|c|}
\hline \multirow[t]{2}{*}{ Description } & Nigeria & Malaysia \\
\hline & \multicolumn{2}{|c|}{ Administrative/Constitutional Control } \\
\hline \multirow{2}{*}{$\begin{array}{l}\text { Ownership of } \\
\text { ports }\end{array}$} & Federal Government & State and Federal Governments \\
\hline & \multicolumn{2}{|c|}{ Maritime Monitoring Agencies } \\
\hline $\begin{array}{l}\text { Privatisation of } \\
\text { Port and Maritime } \\
\text { Security }\end{array}$ & $\begin{array}{l}\text { Surveillance activities } \\
\text { of NIMASA is firmed } \\
\text { out to a private } \\
\text { company }\end{array}$ & $\begin{array}{l}\text { MMEA exercises the power of } \\
\text { surveillance }\end{array}$ \\
\hline \multirow[t]{2}{*}{$\begin{array}{l}\text { Implementation of } \\
\text { the ISPS Code }\end{array}$} & $\begin{array}{l}\text { Saddles NIMASA with } \\
\text { the responsibility, but } \\
\text { not effective }\end{array}$ & $\begin{array}{l}\text { MMEA not concerned with the } \\
\text { implementation of the Code }\end{array}$ \\
\hline & \multicolumn{2}{|c|}{ Customs and Immigration } \\
\hline $\begin{array}{l}\text { Manual inspection } \\
\text { of containers }\end{array}$ & $\begin{array}{l}\text { Manual inspection of } \\
\text { containers is still in } \\
\text { practice }\end{array}$ & $\begin{array}{l}\text { Electronic inspection is in } \\
\text { practice }\end{array}$ \\
\hline Basic Amenities & $\begin{array}{l}\text { Basic amenities like } \\
\text { electricity remains } \\
\text { ineffective and affects } \\
\text { their efficiency }\end{array}$ & $\begin{array}{l}\text { Its availability is aiding their } \\
\text { efficiency }\end{array}$ \\
\hline
\end{tabular}




\section{REGIONAL COOPERATION}

Regional cooperation happens to be one of Malaysia's defense of its port and maritime security. Regional cooperation has given rise to the formation of the Five Power Defense Arrangement (FPDA) between the member states to wit Australia, Malaysia, Singapore, United Kingdom, and New Zealand. The FPDA is the highest military expert forum, and it serves as an imperative platform for the exchange of ideas among the defense chiefs (Lt Faliq, 2015). Bearing in mind the non-traditional threats to port and maritime security, especially the prominent role which the defence forces have undertaken in rendering humanitarian assistance, this regional cooperation's ability to develop and adapt to this varying environment over the years has made it possible for it to remain relevant (Lt Faliq, 2015). This kind of arrangement is important to preserve regional peace and stability, sustain economic viability, and improve the training of the maritime enforcement personnel for the benefit of all countries.

Nigeria and some other neighboring countries are also enjoying cooperation to combat maritime insecurity. Countries like Congo, Ghana, Sierra Leone, etc. are teaming up in this regard. Nevertheless, there appears to be a lack of commitment, unlike what is obtainable in South-east Asia. Although, a few days ago, the Nigerian navy seemingly encouraging regional cooperation-in the Cameroonian waters. It is not in doubt that no state can be an island in itself to combat transnational crimes alone without the aid of other states. Enforcement operations between different states require reliable international cooperation. There have been measures to combat counter-terrorism cooperatives between the Five Power Defence Arrangements (FPDA), which consists of Australia, Britain, Malaysia, Singapore, and New-Zealand. The concern over maritime security has attracted the attention of external powers, thereby bringing about rivalry within the region. The U.S tried to improve security in the Straits of Malacca with the aid of regional allies, but China has expressed concern over the U.S's ability to disrupt its access. (Andrew TH Tan, 2010).

Regional cooperation in fighting ports and maritime security transcends different states borders, and to this end, there is a need to develop the following strategies:

i. Information sharing mechanism between the states;

ii. Establishment of a decision-making regime and strategy for responses to eventualities; 
i. Identification of weakness in the states' enforcement mechanism, either institution or regulatory;

ii. Smart intelligence needs to be collected, interpreted, analyzed, shared, recorded, used and acted upon efficiently and effectively among the maritime security stakeholders; and

iii. Adequate resources need to be provided to procure equipment (Nazery Khalid, 2010).

\section{CONCLUSION}

An assessment of the laws regulating maritime security in both Nigeria and Malaysia indicates that there are areas of interface between Nigeria and Malaysia, which could benefit both countries if harnessed. One of the areas of distinction identified in this paper is the issue of qualifications of the Director-General of NIMASA and MMEA. It is established that for a person to be appointed as a Director-General of the Nigerian Maritime Administration and Safety Agency, he/she must have extensive knowledge of maritime affairs. But in the case of Malaysia, it is observed that the Act is silent on the qualifications of a civil servant to be appointed as the DirectorGeneral of the MMEA. This paper posits that the gap needs to be addressed by inserting a provision in the Act that will make only a civil servant with requisite knowledge of port and maritime security to be appointed as the Director-General; otherwise, the agency may not achieve its mandate if a non-technocrat is put at the helm of affairs. The paper demonstrated that the legal regimes of Nigeria and Malaysia on port security are virtually the same with little differences. However, there is a lot to be learned from the implementation strategies of the Malaysian port and maritime security agencies.

\section{REFERENCES}

Abdulkadir, A.O. (2015). Maritime Pirates: The Criminal Underworld of the Nigerian Maritime Domain. The Gravitas Review of Business and Property Law, 6 (2): 77.

Abdulkadir, A.O. (2013). Preventing Armageddon: Implementation of the International Ship and Port Facility Security (ISPS) Code in Nigeria. Ife Juris Review, Journal of Contemporary Legal and Allied Issues, IFJR, Part 2, 349. 
Ahmad Ibrahim. (1974). Malaysia as a Federation. Journal of Malaysia and Comparative Law, 7. See also

Ahmad Ibrahim. (1997). Family Law in Malaysia, $3^{\text {rd }}$ Edition. Malaysia: Butterworth

Andrew TH Tan. (2010). The Asian Countries' Interest in Asian Energy Security. Energy Issues in the Asia-Pacific Region, 3-23.

Ganapathiraju Pramod and Tony, J. (25 ${ }^{\text {th }}$ October, 2018). An Estimation of Compliance of the Fisheries of Nigeria with Article 7 (Fisheries Management) of the U.N. Code of Conduct for Responsible Fishing." Available at ftp://ftp.fisheries.ubc.ca/CodeConduct/.../Nigeria-CCRF. pdf

Gold, E. (1981). Maritime Transport - The Evolution of International Marine Policy and Shipping Law. Toronto: D.C Heath and Company.

"Malaysia to Prepare Law on Biological Warfare" available on http://www. klpos.com/analysis/6831-keeping-biological-weapons-in-check-inmalaysia (accessed on 10/4/19).

"Malaysia Prepare Biological Conventions Implementation Legislation", available at http://www.nti.org/gsn/article/malaysia-prepares biological-weapons-convention-implementation-legislation/ (accessed on 10/4/19).

Nazery Khalid. (2010). In Port We Port Trust: The Economic Consequence of Attacks on Ports. Andrew Forbes (ed.), 89.

Ogah P. (15 ${ }^{\text {th }}$ September, 2012). Law and Security in Nigeria: The Role of the Military. Available at http://:LBrigadierGeneralOgahPdf.

Okeke V.O.S and Aniche E.T. (2012). An Evaluation of the Effectiveness of the Cabotage Act, 2003 on Maritime Administration. Sacha Journal of Policy and Strategic Studies, 2 (1): 12-13.

S.O. Ntuks $v$ NPA, SC.190/2003, delivered on 11 ${ }^{\text {th }}$ May, 2007.

Sharifah Suhana Ahmad (1999). Malaysian Legal System. Kuala Lumpur: Butterworth

Surinder Singh v The Government of the Federation of Malaya (1962) MLJ 169.

Tun Mohammad Suffian Bin Hasim. (1976). An Introduction to the Constitution of Malaysia, $2^{\text {nd }}$ Edition. Kuala Lumpur: Malayan Law Journal, 18-19.

Tunku Sofiah Jewa. (1996). Law of the Sea in Public International Law:

A Malaysian Perspective, Volume II. Kuala Lumpur: Pacifia publications.

United States v Fores, 289 U.S 137, 155-159 and Cunard Steamship Co. v Mellon, 262 U.S. 100. 124.

Zweigert, K. and Kotz, H. (1987). Introduction to Comparative Law. Oxford: Clarendon Press. 